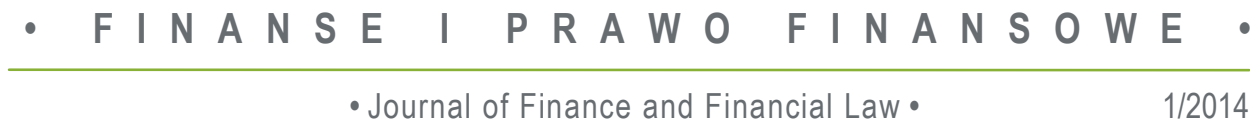

https://doi.org/10.18778/2391-6478.1.1.04

Wioletta Barbara Pierzchalska

Mgr, Uniwersytet Łódzki, Wydział

Ekonomiczno-Socjologiczny,

Instytut Finansów

\title{
ANALIZA FINANSOWA ORAZ MODELE PRZEWIDYWANIA UPADŁOŚCI JAKO NARZĘDZIE OCENY KONDYCJI FINANSOWEJ PRZEDSIĘBIORSTWA
}

\begin{abstract}
Streszczenie
Wczesne rozpoznanie pojawiającego się zagrożenia upadłością jest warunkiem koniecznym dla możliwości podjęcia szybkich działań naprawczych i uniknięcia bankructwa. Wczesna detekcja jest umożliwiona dzięki istnieniu modeli wczesnego ostrzegania. W artykule autor starał się podsumować mocne i słabe strony analizy finansowej oraz modeli wczesnego ostrzegania w monitorowaniu sytuacji finansowej przedsiębiorstwa, by być w stanie wychwycić potencjalne sygnały niebezpieczeństwa bankructwa. Plusy i minusy obu metod są zwykle uważane za oczywiste i naturalne, lecz gdy zachodzi potrzeba wybrania jednej z nich, bądź uzupełnienia wybranej brakującymi danymi, staje się to trudne przez niedostateczną świadomość zalet i wad analizy finansowej bądź modeli upadłościowych. Co więcej, świadomość mocnych i słabych stron tych metod, pozwala w dogłębniejszy sposób zrozumieć ich specyfikę i użyć lepszą metodę, bądź być w stanie uzupełnić wybraną brakującymi danymi, by dopełnić obraz sytuacji finansowej przedsiębiorstwa. Artykuł zawiera najczęściej spotykane przyczyny upadłości, ogólną klasyfikację metod badania bankructwa oraz większość wad i zalet analizy finansowej oraz modeli wczesnego ostrzegania.

Słowa kluczowe: prognozowanie upadłości, analiza finansowa, modele dyskryminacyjne, porównanie metod, przyczyny bankructwa, plusy i minusy.

\section{WPROWADZENIE}

Upadłość przedsiębiorstw jest nieodłącznym elementem cyklu życiowego w gospodarce rynkowej. Jej istnienie jest tak samo naturalne, jak pojawianie się nowych przedsiębiorstw. Jednakże przy obecnym stanie wiedzy nie trzeba całkowicie godzić się na to, że w pewnym momencie firma nagle przestanie istnieć. Zwykle występują pewne symptomy, jakie wcześniej sygnalizują zbliżające się niebezpieczeństwo bankructwa, kwestią jest tylko ich szybkie zauważenie, odczytanie i odpowiednia reakcja.
\end{abstract}


Wczesne rozpoznanie pojawiającego się zagrożenia upadłością jest warunkiem koniecznym dla możliwości podjęcia szybkich działań naprawczych i uniknięcia bankructwa. Wczesna detekcja jest umożliwiona dzięki istnieniu modeli wczesnego ostrzegania i może być stosowana przez przedsiębiorstwa w celu monitorowania własnej sytuacji finansowej. Przy odpowiedniej wiedzy na temat danych finansowych kontrahentów, modele mogą być stosowane w celu szacowania zasadności udzielania kredytów kupieckich, bądź przez instytucje bankowe w celu oceny zdolności kredytowej klientów. Kolejnym polem do stosowania modeli wczesnego ostrzegania są biura maklerskie, które mogą z wykorzystaniem funkcji dyskryminacyjnych określać pozycję ratingową badanej spółki. Z punktu widzenia interesariuszy, szybszą odpowiedź o stanie przedsiębiorstwa mogą dać modele wczesnego ostrzegania i dopiero na podstawie wyniku uzyskanego z ich wykorzystaniem, można dochodzić do źródła powstania problemu wykorzystując pracochłonną i bardziej złożoną analizę finansową.

Wiedza na temat niedoskonałości używanych narzędzi jest bardzo ważna szczególnie gdy ma ona służyć uniknięciu bankructwa przedsiębiorstwa. Dzięki niej można odpowiednio uzupełnić badania o brakujące elementy. W artykule autor starał się przedstawić słabe i mocne strony analizy finansowej oraz modeli przewidywania bankructwa w monitorowaniu sytuacji finansowej przedsiębiorstwa by jak najbardziej efektywnie przeciwdziałać temu zjawisku.

Celem pracy było zgromadzenie $w$ jednym opracowaniu mocnych i słabych stron stosowania modeli wczesnego ostrzegania i analizy finansowej w przewidywaniu upadłości przedsiębiorstw. Plusy i minusy wyżej wymienionych metod są uważane za oczywiste, lecz gdy zachodzi potrzeba wybrania jednej z nich, bądź uzupełnienia wybranej brakującymi danymi, staje się to trudne przez niedostateczną świadomość zalet i wad analizy finansowej bądź modeli upadłościowych.

Autor zakłada, że nie można jednoznacznie stwierdzić o wyższości jednej metody nad drugą, ze względu na ich komplementarny charakter oraz fakt, iż oba sposoby prognozowania upadłości mają niedoskonałości, które to mogą być uzupełnione przez zastosowanie drugiej metody.

W artykule przedstawiono najbardziej popularne teorie upadłości, ogólne klasyfikacje metod przewidywania bankructwa oraz mocne i słabe strony analizy finansowej oraz modeli predykcji bankructwa.

\section{PRZYCZYNY UPADLOŚCI PRZEDSIĘBIORSTW}

Współczesna gospodarka charakteryzuje się dużą zmiennością, rosnącą konkurencją, presją czasu, standaryzacją procesów i struktur, zmianami warunków ekonomicznych i prawnych na rynku pracy. Wszystko to, powoduje zagrożenie funkcjonowania przedsiębiorstw [Kowalczyk 2005: 118]. 
Upadłość przedsiębiorstw jest zjawiskiem bezpośrednio związanym z funkcjonowaniem gospodarki rynkowej. Istnieją firmy, które znalazły sposób na długowieczność i ograniczanie wypływu zmian cyklu koniunkturalnego na działalność firmy, lecz większość ulega okresowym problemom związanymi z niewypłacalnością, likwidacją czy bankructwem. Zjawisko upadłości jest bardzo złożone i jego przyczyn upatrywać można w warunkach ekonomicznych, prawnych, społecznych, a nawet psychologicznych [Prusak 2007: 9].

Do tej pory powstało wiele teorii dotyczących upadłości przedsiębiorstw. Wybrane $\mathrm{z}$ nich prezentowane są $\mathrm{w}$ tab. 1 .

Tabela 1. Elementy teorii bankructwa w wybranych teoriach przedsiębiorstwa

\begin{tabular}{|l|l|}
\multicolumn{1}{|c|}{$\begin{array}{c}\text { Teoria } \\
\text { przedsiębiorstwa }\end{array}$} & \multicolumn{1}{c|}{ Elementy teorii bankructwa } \\
$\begin{array}{l}\text { Neoklasyczna teoria } \\
\text { A. Marshalla }\end{array}$ & $\begin{array}{l}\text { Upadłość jest konsekwencją odstąpienia przedsiębiorstwa od maksy- } \\
\text { malizacji zysku. Wpływając na zmianę zaangażowania zasobów, } \\
\text { oddziałuje korzystnie na gospodarkę. }\end{array}$ \\
\hline $\begin{array}{l}\text { Teoria } \\
\text { przedsiębiorczości } \\
\text { J. Schumpetera }\end{array}$ & $\begin{array}{l}\text { Upadłość nieefektywnych i nieinnowacyjnych przedsiębiorstw jest } \\
\text { warunkiem rozwoju gospodarki jako całości. Z tego powodu bankruc- } \\
\text { two jest korzystne dla gospodarki. }\end{array}$ \\
\hline Nurty instytucjonalne & $\begin{array}{l}\text { Skala i tempo procesów upadłościowych w gospodarce są uwarunko- } \\
\text { wane jakością instytucjonalnej infrastruktury upadłości. Zwraca się, } \\
\text { jednak uwagę, że bankructwo, spowodowane istnieniem kosztów } \\
\text { transakcyjnych i problemem agencji, może mieć negatywne skutki } \\
\text { w skali makro- i mikroekonomicznej. }\end{array}$ \\
\hline Teorie menedżerskie & $\begin{array}{l}\text { Uniknięcie bankructwa jest warunkiem realizacji celów, do jakich } \\
\text { dążą zarządzający. Upadłość wyklucza korzyści menedżerów. Jest } \\
\text { również niekorzystna dla właścicieli i innych grup związanych } \\
\text { z przedsiębiorstwem. }\end{array}$ \\
\hline Teorie biologiczne & Bankructwo jest naturalnym elementem cyklu życia przedsiębiorstwa. \\
\hline $\begin{array}{l}\text { Teoria wartości dla } \\
\text { akcjonariuszy }\end{array}$ & $\begin{array}{l}\text { Dążenie do maksymalizacji wartości dla akcjonariuszy zapewnia } \\
\text { przetrwanie przedsiębiorstwa w długim okresie. Upadłość wyklucza } \\
\text { realizację przez przedsiębiorstwo postulatu maksymalizacji wartości, } \\
\text { jest zatem niekorzystna dla właścicieli. }\end{array}$ \\
\hline
\end{tabular}

Źródło: Pieńkowska [2005: 27].

W obecnych czasach nie dziwią informacje o kryzysach w kolejnych przedsiębiorstwach, o dużych firmach ogłaszających upadłość, czy masowych zwolnieniach spowodowanych trudną sytuacją przedsiębiorstwa. Przyczyn tego typu problemów szukać można zarówno w otoczeniu firmy, jak i wewnątrz niej. Nagromadzenia negatywnych zmian, brak odpowiedniej reakcji, pogarszające się działanie podstawowych funkcji przedsiębiorstwa implikuje powstanie kryzysu [Kozyra 2002: 203-205]. 
Ścieżkę dochodzenia przedsiębiorstwa do kryzysu przedstawiono na rys. 1. Klasyczny mechanizm pojawiania się kryzysu w przedsiębiorstwie ma swój początek w spadku popytu na oferowane produkty i produkcję poniżej progu rentowności, co daje efekt $\mathrm{w}$ postaci obniżenia płynności. Pojawiają się problemy z finansowaniem działalności przedsiębiorstwa oraz z zadłużeniem krótkoterminowym. Brak reakcji ze strony zarządzających może doprowadzić do utraty płynności i nadmiernego zadłużenia, a to w konsekwencji do upadłości [Pawłowicz 2003: 17].

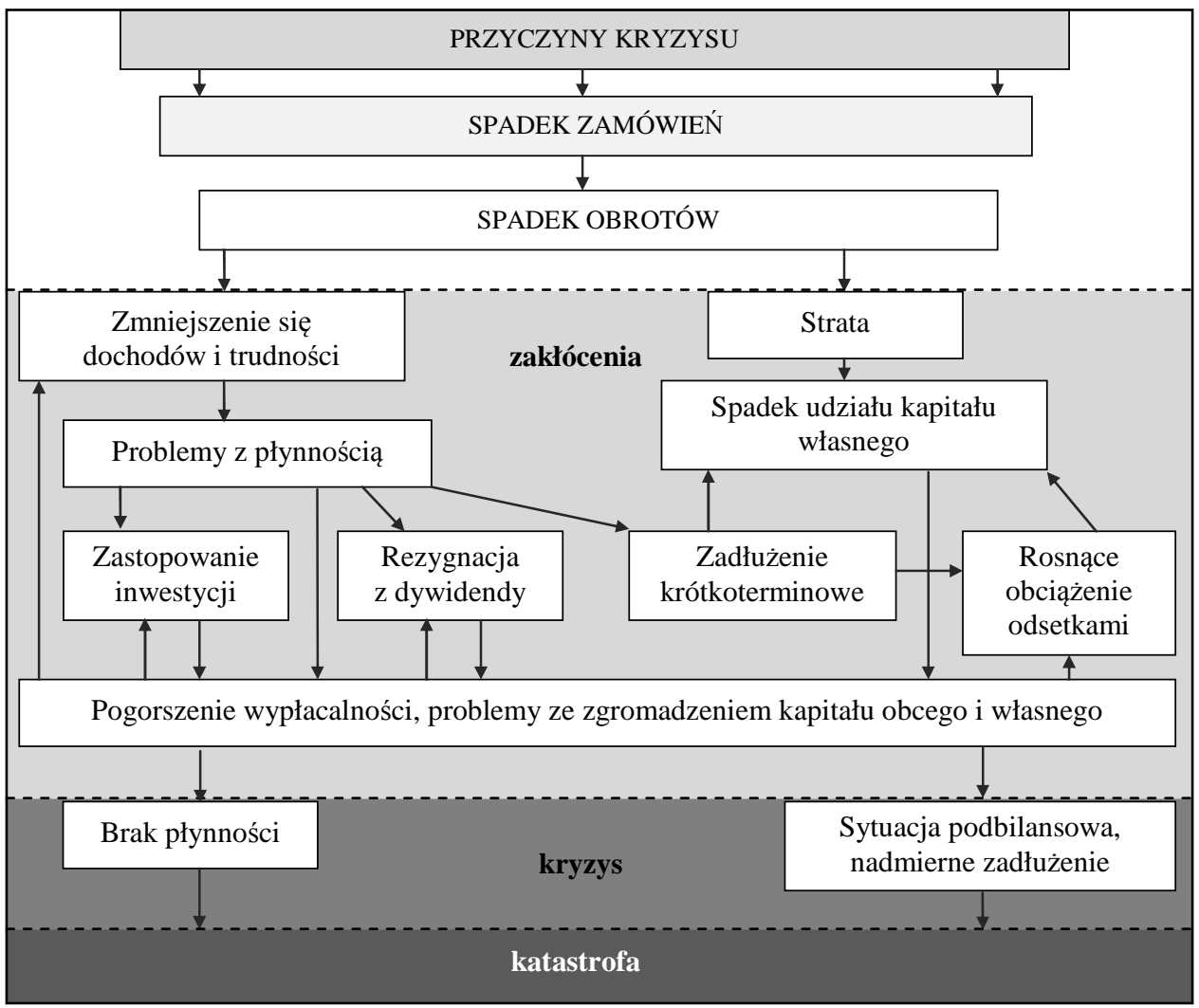

Rys. 1. Klasyczny mechanizm kryzysu przedsiębiorstwa

Źródło: Pawłowicz [2003: 17].

Podsumowując dotychczasowe rozważania, można skonstruować wniosek ogólny, iż pogarszająca się sytuacja przedsiębiorstwa jest powodowana przez kilka czynników jednocześnie. Częstą sytuacją jest efekt domina, czyli powstające problemy powodują kolejne, np. pogarszająca się jakość wpływa na wiel- 
kość sprzedaży, co bezpośrednio wpływa na sytuację finansową przedsiębiorstwa [Zelek 2003: 55].

Znając podłoże powstawania problemów funkcjonowania przedsiębiorstwa, kolejnym krokiem jest monitorowanie, badanie sytuacji firmy oraz prowadzenie prognoz w celu niedopuszczenia do sytuacji, w której przedsiębiorstwo musiałoby zostać postawione $\mathrm{w}$ stan upadłości.

\section{KLASYFIKACJA METOD PROGNOZOWANIA UPADŁOŚCI PRZEDSIĘBIORSTW}

Według E. Mączyńskiej, ze względu na dużą niepewność i narastające ryzyko, w obecnych czasach istotne jest wykorzystywanie odpowiednich metod w celu wczesnej identyfikacji zagrożeń w biznesie [Mączyńska 2010: 21].

Podział modeli prognozowania powszechny w literaturze zachodniej przedstawia T. Korol [2010: 93].Wyróżnił on trzy grupy metod prognozowania upadłości: metody statystyczne, metody miękkich technik obliczeniowych oraz modele teoretyczne, co przedstawiono w tab. 2.

Tabela 2. Ogólna klasyfikacja metod i modeli prognozowania upadłości

\begin{tabular}{|c|c|c|}
\hline Metody statystyczne & $\begin{array}{c}\text { Metody miękkich technik } \\
\text { obliczeniowych }\end{array}$ & Modele teoretyczne \\
\hline $\begin{array}{c}\text { Modele analizy } \\
\text { dyskryminacyjnej }\end{array}$ & Sztuczne sieci neuronowe & Modele teorii entropii \\
\hline Modele logitowa & Logika rozmyta & Modele hazardowe \\
\hline Modele probitowe & Algorytmy genetyczne & $\begin{array}{c}\text { Modele ryzyka } \\
\text { kredytowego }\end{array}$ \\
\hline Drzewa decyzyjne & Modele wektorów nośnych & \\
\hline
\end{tabular}

\section{Źródło: Korol [2010: 93].}

Zgodnie z wynikami badań Aziza i Dara [2006: 18-33] najczęściej wykorzystywane, bo aż w $64 \%$ przypadków, są metody statystyczne, w $25 \%$ metody miękkich technik obliczeniowych, zaś w zaledwie $11 \%$ metody teoretyczne. Jeśli chodzi o konkretne rodzaje metod prognozowania upadłości, to najpopularniejsze są modele dyskryminacyjne, które są wykorzystywane w ponad $30 \%$ analiz. Kolejną popularną metodą jest analiza logitowa, następnie sieci neuronowe i drzewa decyzyjne. Prawie $34 \%$ stanowią pozostałe metody, takie jak klasyczna analiza wskaźnikowa, regresja liniowa, systemy ekspertowe, teoria chaosu i inne. 


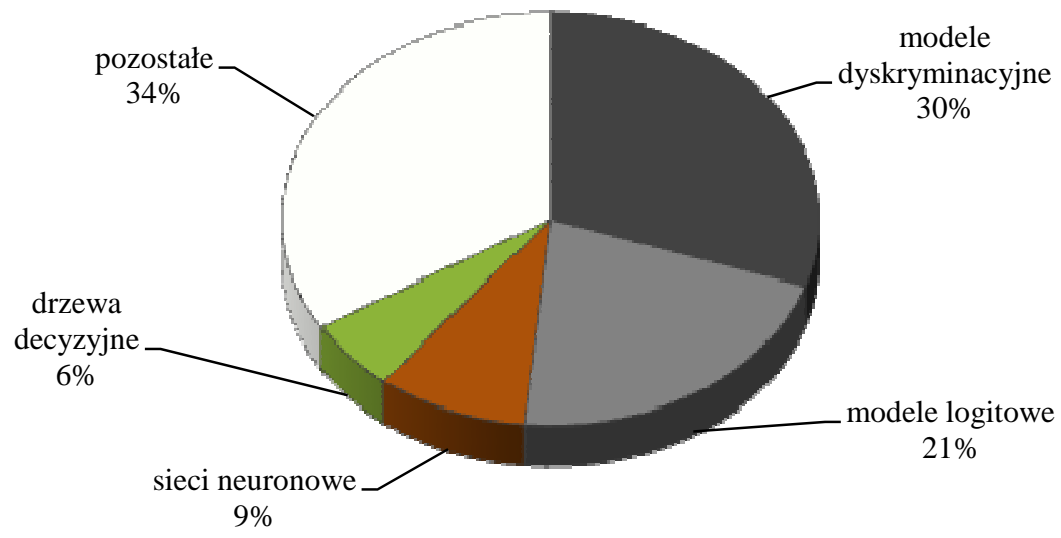

Wykres 1. Techniki prognozowania upadłości na świecie

Źródło: opracowanie własne na podstawie Aziz i Dar [2006: 18-33].

Jedne z najszerzej zakrojonych badań nad skutecznością modeli dyskryminacyjnych przeprowadził Paweł Antonowicz [2007]. Przeanalizował pod kontem skuteczności aż 52 modele dyskryminacyjne (36 polskich oraz 16 zagranicznych modeli) na próbie 208 przedsiębiorstw. Najlepszą dziesiątkę funkcji dyskryminacyjnych, zgodnie z wynikami badań Antonowicza, przedstawia tab. 3.

Patrząc na uśrednioną skuteczność modeli (średnia skuteczność na rok i dwa lata przed upadłością), można uznać za zasadne ich stosowanie, a co za tym idzie ich popularność.

Jeżeli problem stałości kontynuacji działalności gospodarczej jest tak ważny, to należy zastanowić się nad tym, która metoda prognozowania bankructwa będzie bardziej zasadna w użyciu. Rozważaniom poddane będą: popularna, ale bardzo pracochłonna analiza finansowa oraz szybkie i łatwe w zrozumieniu modele dyskryminacyjne. Obie metody mają niezaprzeczalne plusy, ale również i minusy.

\section{ANALIZA FINANSOWA I JEJ OGRANICZENIA}

Analiza wskaźnikowa jest narzędziem dostarczającym informacji o sytuacji finansowej przedsiębiorstwa z wykorzystaniem szeregu powiązań między elementami sprawozdania. Wartości tych powiązań, ich zmiany i wzajemne relacje umożliwiają ocenę działalności i stanowią podstawę do formułowania prognoz [Gajdzik 2011: 124-125]. 
Tabela 3. Dziesięć modeli dyskryminacyjnych o najlepszej średniej sprawności zgodnie $\mathrm{z}$ badaniami P. Antonowicza

\begin{tabular}{|c|c|c|c|c|}
\hline L.p. & $\begin{array}{l}\text { Nazwa i autorzy } \\
\text { modelu }\end{array}$ & Wzór & $\begin{array}{l}\text { Średni } \\
\text { błąd }\end{array}$ & $\begin{array}{l}\text { Średnia } \\
\text { sprawność }\end{array}$ \\
\hline 1 & $\mathrm{Z7}_{\text {INE PAN }}$ & $\begin{array}{c}9,498 X_{1}+3,566 X_{2}+2,903 X_{3}+ \\
+0,452 X_{4}-1,498\end{array}$ & $5,18 \%$ & $94,82 \%$ \\
\hline 2 & Z6 INE PAN & $\begin{array}{c}9,478 X_{1}+3,613 X_{2}+3,246 X_{3}+ \\
+0,455 X_{4}+0,802 X_{5}-2,478\end{array}$ & $5,8 \%$ & $94,2 \%$ \\
\hline 3 & $\begin{array}{l}\mathrm{Z}_{\mathrm{ME}}-\text { E. Mączyńskiej } \\
\text { (funkcja Jacobsa) }\end{array}$ & $\begin{aligned} 1,50 X_{3}+ & 0,08 X_{6}+10,00 X_{7}+5,00 X_{8}+ \\
& +0,30 X_{9}+0,10 X_{10}\end{aligned}$ & $5,18 \%$ & $94,82 \%$ \\
\hline 4 & $\begin{array}{c}\mathrm{Z}_{\mathrm{HCP}}-\text { „Poznański” - } \\
\text { M. Hamrol, B. Czajka, } \\
\text { M. Piechocki }\end{array}$ & $\begin{array}{c}3,562 X_{11}+1,588 X_{12}+4,288 X_{13}+ \\
+6,719 X_{14}-2,368\end{array}$ & $6,22 \%$ & $93,78 \%$ \\
\hline 5 & $\mathrm{Z}_{\mathrm{BP} 1}-\mathrm{B}$. Prusaka & $\begin{array}{c}6,5245 X_{1}+0,1480 X_{15}+0,4061 X_{4}+ \\
+2,1754 X_{16}-1,5685\end{array}$ & $7,48 \%$ & $92,52 \%$ \\
\hline 6 & $\mathrm{Z}_{\mathrm{BP} 2}-\mathrm{B}$. Prusaka & $\begin{array}{c}1,4383 \mathrm{X}_{3}+0,1878 \mathrm{X}_{15}+ \\
+5,0229 \mathrm{X}_{5}-1,8713 \\
\end{array}$ & $8,19 \%$ & $91,81 \%$ \\
\hline 7 & $\mathrm{Z}_{\mathrm{DW}}-\mathrm{D}$. Wierzby & $3,26 X_{17}+2,16 X_{18}+0,69 X_{19}+0,30 X_{20}$ & $8,29 \%$ & $91,71 \%$ \\
\hline 8 & $\mathrm{Z}_{\mathrm{A} 3}-$ E. I. Altmana & $1,2 X_{21}+1,4 X_{11}+3,3 X_{7}+0,6 X_{22}+X_{5}$ & $8,55 \%$ & $91,45 \%$ \\
\hline 9 & $\begin{array}{l}\mathrm{Z}_{\mathrm{A} 1}-\text { E. I. Altmana } \\
\text { (1968 r.) }\end{array}$ & $\begin{array}{c}0,717 X_{21}+0,847 X_{11}+3,107 X_{7}+ \\
+0,420 X_{22}+0,998 X_{5}\end{array}$ & $10,27 \%$ & $89,73 \%$ \\
\hline 10 & $\begin{array}{l}\mathrm{Z}_{\mathrm{A} 2}-\text { E. I. Altmana } \\
\text { (1984 r.) }\end{array}$ & $6,56 X_{21}+3,26 X_{11}+6,72 X_{7}+1,05 X_{22}$ & $10,70 \%$ & $89,30 \%$ \\
\hline
\end{tabular}

$\mathrm{X}_{1}$ - wynik operacyjny/wartość aktywów

$\mathrm{X}_{2}$ - wartość kapitału własnego/wartość aktywów

$\mathrm{X}_{3}$ - (wynik finansowy netto + amortyzacja)/suma zobowiązań

$\mathrm{X}_{4}$ - aktywa obrotowe/zobowiązania krótkoterminowe

$\mathrm{X}_{5}-$ przychody ze sprzedaży/wartość aktywów

$\mathrm{X}_{6}$ - suma bilansowa/zobowiązania

$\mathrm{X}_{7}$ - roczny wynik finansowy przed opodatkowaniem/suma bilansowa

$\mathrm{X}_{8}$ - roczny wynik finansowy przed opodatkowaniem/roczne przychody

$\mathrm{X}_{9}$ - zapasy/roczne przychody

$\mathrm{X}_{10}$ - roczne przychody/suma bilansowa

$\mathrm{X}_{11}$ - wynik finansowy netto/majątek całkowity

$\mathrm{X}_{12}$ - (majątek obrotowy - zapasy)/zobowiązania krótkoterminowe

$\mathrm{X}_{13}$ - kapitał stały/majątek całkowity

$\mathrm{X}_{14}$ - wynik finansowy ze sprzedaży/przychody ze sprzedaży

$\mathrm{X}_{15}$ - koszty operacyjne (bez pozostałych kosztów operacyjnych)/wartość średnia zobowiązań krótkoterminowych (bez funduszy specjalnych oraz krótkoterminowych zobowiązań finansowych)

$X_{16}$ - wynik z działalności operacyjnej/przychody netto ze sprzedaży

$\mathrm{X}_{17}$ - wynik z działalności operacyjnej - amortyzacja/suma bilansowa

$\mathrm{X}_{18}$ - wynik z działalności operacyjnej - amortyzacja/przychody ze sprzedaży

$\mathrm{X}_{19}$ - kapitał pracujący/przychody ze sprzedaży

$\mathrm{X}_{20}$ - aktywa obrotowe/zadłużenie ogółem

$\mathrm{X}_{21}$ - kapitał pracujący/aktywa ogółem

$\mathrm{X}_{22}$ - rynkowa wartość kapitału własnego/kapitał obcy

Źródło: opracowanie własne na podstawie: Antonowicz [2007: 188]. 
Dzięki miernikom wykorzystywanym w analizie finansowej można dokładniej przyjrzeć się wybranemu wycinkowi rzeczywistości finansowej przedsiębiorstwa. Z wykorzystaniem wskaźników można głębiej przeanalizować zależności przyczynowo-skutkowe zachodzące w firmie, niż gdyby podejmować decyzje finansowe tylko w oparciu o analizę wstępną sprawozdań. Do wyciągania właściwych wniosków bazujących na wskaźnikach ważne są umiejętności, doświadczenie, a często wyobraźnia i intuicja analityka, który dokonuje oceny [Suszyński 2003: 77-78].

G. K. Świderska [2003: 256] przedstawiła szereg ograniczeń wiążących się ze stosowaniem analizy wskaźnikowej. Zauważa ona, że miary finansowe nie są w stanie przekazać informacji o charakterze niemierzalnym, takich jak: jakość produktu, satysfakcja klienta, poziom wykształcenia czy wiedza pracowników. Elementy te często decydują o pozycji konkurencyjnej przedsiębiorstwa, jego zdolności przetrwania i jego wartości. Mierniki finansowe ze względu na trudności precyzyjnej prognozy często zachęcają menedżerów do przyjęcia myślenia krótkookresowego. Ten stan rzeczy w długim okresie może prowadzić do manipulacji miar finansowych i złych decyzji.

J. Kowalczyk i A. Kusak [2006: 2-3] oraz L. Gąsiorkiewicz [2011: 52] wymieniają zarówno pozytywy, jak i negatywy stosowania analizy wskaźnikowej, co przedstawiono w tab. 4.

Tabela 4. Mocne i słabe strony stosowania analizy wskaźnikowej

\begin{tabular}{|l|l|}
\hline \multicolumn{1}{|c|}{ Korzyści } & \multicolumn{1}{|c|}{ Słabe strony } \\
\hline $\begin{array}{l}\text { Łatwość i szybkość obliczania } \\
\text { wskaźników. }\end{array}$ & $\begin{array}{l}\text { Pojedynczy wskaźnik analizowany w separacji } \\
\text { od pozostałych może dać błędne wnioski. }\end{array}$ \\
\hline $\begin{array}{l}\text { Porównywalność w czasie i możliwość } \\
\text { analizy trendów badanych zjawisk. }\end{array}$ & $\begin{array}{l}\text { Tylko czéść wskaźników ma wzorcowe } \\
\text { wielkości pozwalające określić poprawność } \\
\text { badanych zjawisk. }\end{array}$ \\
\hline $\begin{array}{l}\text { Ze względu na popularność tej analizy } \\
\text { istnieje możliwość porównywania danych } \\
\text { na tle konkurencji zarówno w kraju, jak } \\
\text { i w skali międzynarodowej. }\end{array}$ & $\begin{array}{l}\text { Zmiany zasad rachunkowości, czy } \\
\text { zróżnicowanie jej zasad w różnych krajach } \\
\text { powoduje zaburzenie porównywalności i brak } \\
\text { możliwości oceny badanych zjawisk. }\end{array}$ \\
\hline Łatwość identyfikacji problemów. & Brak wskazania na przyczyny problemu. \\
\hline $\begin{array}{l}\text { Kompleksowa analiza ze względu na dużą } \\
\text { różnorodność wskaźników. }\end{array}$ & $\begin{array}{l}\text { Łatwość nadinterpretacji przez sformułowanie } \\
\text { zbyt daleko idących wniosków i zafałszowanie } \\
\text { rzeczywistości. }\end{array}$ \\
\hline
\end{tabular}

Źródło: opracowanie własne na podstawie: Kowalczyk i Kusak [2006: 2-3]; Gąsiorkiewicz [2011: 52].

M. Marcinkowska [2007: 315] zwraca uwagę na to, by analiza wskaźnikowa była tylko jednym $\mathrm{z}$ elementów oceny przedsiębiorstwa. Powinna ona stanowić 
podstawę do podejmowania decyzji w przedsiębiorstwie, ale tylko przy założeniu jej interpretacji z wykorzystaniem innych analiz zarówno mierzalnych, jak i opisowych. Wyniki analizy wskaźnikowej nie powinny być traktowane, jako „ostateczna wyrocznia", co do sytuacji finansowej firmy i jej możliwości rozwoju.

W. Rogowski [2008: 243-244] podkreśla użyteczność analizy finansowej w przewidywaniu upadłości. Jest ona w dalszym ciągu używana w tym celu, jednakże wymaga od osoby wykorzystującej analizę finansową dość dużej wiedzy z zakresu finansów przedsiębiorstwa, ekonomii i rachunkowości, jak również jest bardzo koszto- $\mathrm{i}$ czasochłonna.

Wszystkie wymienione wątpliwości związane z zastosowaniem analizy finansowej w ocenie zdolności do kontynuacji działalności spowodowały pojawienie się i szybki rozwój modeli służących ocenie zagrożenia upadłością, wykorzystujących dotychczasowy dorobek związany z analizą finansową.

\section{ZALETY I SŁABOŚCI MODELI BANKRUCTWA}

Idąc za prezesem amerykańskiej korporacji ITT H. Greek w 1984 r., który stwierdził, że [cyt. za: Cabała 2008: 5] „dziewięćdziesiąt dziewięć procent wszystkich niespodzianek w biznesie to niespodzianki negatywne", można powiedzieć, że przedsiębiorca prowadzący działalność gospodarczą musi być ciągle czujny i na bieżąco analizować sytuację finansową w firmie, czemu właśnie mają służyć modele wczesnego ostrzegania.

Modele przewidywania bankructwa nie dają odpowiedzi, w którym obszarze szukać problemu i w jaki sposób poprawić sytuację firmy, lecz ich zadaniem jest sygnalizowanie pogarszającej się kondycji przedsiębiorstwa [Zaleska 2002: 12].

Modele upadłościowe są sprawdzonymi w świecie narzędziami ustalania ilościowych miar zagrożenia przedsiębiorstw. Modele te spełniają zasady metodyczne i dają dobrą przewidywalność w prognozowaniu bankructwa. Zastąpienie podejścia intuicyjnego modelami jest uzasadnione istnieniem statystycznych zależności wykrytych w próbie przedsiębiorstw, co daje bardziej obiektywny obraz zastanej rzeczywistości finansowej. Co więcej, stosowanie modeli wymusza spojrzenie na ilościowe charakterystyki bankructwa, a nie tylko sytuacyjne bądź prawne [Gruszczyński 2005: 186].

Słabą stroną modeli przewidywania bankructwa jest dobór próby do badania. Stanowi to poważny problem dla analityków, ponieważ brak jest dobrej bazy danych o jednostkach upadających lub upadłych, a co za tym idzie każdy badacz dobiera własną próbę przedsiębiorstw i nie są to próby losowe, co nie jest statystycznie poprawne [Gruszczyński 2005: 185-186].

$\mathrm{Z}$ punktu widzenia badań, zaliczenie przedsiębiorstwa do grona upadłych może nastręczać wiele trudności, ponieważ najczęściej spotykaną praktyką jest 
określenie przedsiębiorstwa jako upadłe na podstawie informacji ogłoszonej przez sąd o wszczęciu postępowania układowego (gdzie zgodnie z polskim prawem upadłościowym i naprawczym postępowanie to stanowi część postępowania upadłościowego) bądź naprawczego [Prusak 2005: 13].

Kolejnym problemem jest brak porównywalności w zakresie wielkości próby jak i czasu przeprowadzanych badań. $\mathrm{W}$ jednych badaniach próba składała się z 10 przedsiębiorstw, jak w przypadku liniowej wielowymiarowej analizy dyskryminacyjnej M. Pogodzińskiej i S. Sojaka [1995: 53-61], a inne z prawie dziesięciu tysięcy przedsiębiorstw, co niewątpliwie wpływa na wiarygodność i użyteczność uzyskanych modeli.

Słabością polskich modeli prognozowania upadłości jest też brak dodatkowych informacji o charakterze niefinansowym. Modele te korzystają głównie ze zmiennych finansowych, ponieważ do informacji takich jak nadzór korporacyjny jest niezmiernie trudno dotrzeć [Gruszczyński 2005: 186-187].

B. Prusak [2005: 63] przedstawia zarówno zalety, jak i wady stosowania funkcji dyskryminacyjnych. Zwraca on uwagę na prostotę i zrozumiałość stosowania oraz interpretacji tych metod, ale jako ich wadę wymienia niestabilność w czasie, uzyskiwanie w wielu przypadkach gorszych wyników klasyfikacji w porównaniu do technik, takich jak sztuczne sieci neuronowe czy analiza logitowa oraz liniową zależność między zmienną objaśniającą i objaśnianą. W rzeczywistości zależność między zmiennymi a sytuacją finansową spółki jest nieliniowa.

Modele oceny zagrożenia finansowego przedsiębiorstw znalazły zastosowanie w wielu gałęziach finansów, między innymi w bankach, instytucjach ratingowych, są również stosowane przez biegłych rewidentów, osoby zarządzające przedsiębiorstwem, zarówno w celu monitorowania własnej firmy oraz by zbadać wiarygodność kontrahentów i inne. W ocenie ryzyka niewypłacalności wykorzystuje się coraz częściej metody statystyczne. Ich skomplikowany proces obliczania jest znacznie upraszczany przez liczne programy komputerowe, dzięki którym problematyka przewidywania ryzyka upadłości staje się coraz mniej intuicyjna, a zauważenie problemów przedsiębiorstwa może być, nie tylko zaobserwowane wcześniej, ale również udokumentowane obiektywnymi danymi finansowymi [Prusak 2005: 8].

\section{PODSUMOWANIE}

Ryzyko upadłości, które towarzyszy prowadzeniu działalności gospodarczej dzięki istniejącym mechanizmom może być w obecnych czasach skutecznie minimalizowane poprzez wczesną detekcję pogarszającej się sytuacji finansowej przedsiębiorstwa. 
Poddane rozważaniom dwie metody, analiza finansowa i modele dyskryminacyjne posiadają zarówno wady, jak i zalety związane $\mathrm{z}$ ich charakterystyką i bezpośrednim celem ich stosowania. Analiza finansowa używana do szczegółowego badania sytuacji finansowej przedsiębiorstwa może wskazać, w którym obszarze działalności tkwi problem, zaś modele wczesnego ostrzegania mogą w łatwy i szybki sposób zasygnalizować pogarszającą się sytuację firmy.

Hipoteza postawiona przez autora została potwierdzona, dzięki czemu z łatwością można odpowiedzieć na pytanie, w jakim celu stosować jeszcze modele bankructwa, jeśli firma wykorzystuje obszerne analizy finansowe. Analiza finansowa i modele dyskryminacyjne mogą stanowić świetny mechanizm obronny przedsiębiorstwa i ze względu na ich charakter mogą się wzajemnie uzupełniać. Modele dyskryminacyjne dają ogólny sygnał o tym, że przedsiębiorstwo może być zagrożone upadkiem, ale dopiero analiza finansowa i dogłębne badanie pozwoli na detekcję punktu zapalnego i danie odpowiedzi, co należy zrobić by uporać się z kryzysem.

\section{BIBLIOGRAFIA}

Antonowicz P., 2007, Metody oceny i prognoza kondycji ekonomiczno-finansowej przedsiębiorstwa, Ośrodek Doradztwa i Doskonalenia Kadr, Gdańsk.

A z i z M., D a r H., 2006, Predicting corporate bankruptcy - where we stand?, „Corporate Governance Journal", vol. 6, no. 1.

C a b ał a P., 2008, Systemy wczesnego ostrzegania w przedsiębiorstwie, Wydawnictwo Uniwersytetu Ekonomicznego w Krakowie, Kraków.

Gajdzik B., 2011, Finanse przedsiębiorstwa dla inżynierów, Wydawnictwo Politechniki Śląskiej, Gliwice.

Gą s i o rki e wi c z L., 2011, Analiza ekonomiczno-finansowa przedsiębiorstw, Oficyna Wydawnicza Politechniki Warszawskiej, Warszawa.

Gru szczyński M., 2005, Zalety i stabości modeli bankructwa, [w:] K. Ku ciński, E. Mąc zyńska (red.), Zagrożenie upadtościa, Instytut Funkcjonowania Gospodarki Narodowej, Szkoła Główna Handlowa, Warszawa.

K or ol T., 2010, Systemy ostrzegania przedsiębiorstw przed ryzykiem upadtości, Oficyna a Wolters Kluwer Business, Warszawa.

Kowalczyk J., Kusak A., 2006, Decyzje finansowe firmy. Metody analizy, Wydawnictwo C. H. Beck, Warszawa.

Kowalczyk L., 2005, Narzędzia diagnostyczne umożliwiajace wczesne ostrzeganie przedsiębiorstw przed upadtościa, [w:] E. Mączyńska (red.), Ekonomiczne aspekty upadtości przedsiębiorstw w Polsce, Szkoła Główna Handlowa, Warszawa.

Ko zy r a B., 2002, Alianse strategiczne jako narzędzie zarzadzania przedsiębiorstwem $w$ kryzysie, [w:] B. Ko zy ra, A. Zelek (red.), Praktyka zarzadzania kryzysem w przedsiębiorstwie, Wydawnictwo Zachodniopomorskiej Szkoły Biznesu, Szczecin.

Mąc zyńska E. (red.), 2010, Meandry upadtości przedsiębiorstw, klęska czy druga szansa, Szkoła Główna Handlowa w Warszawie, Warszawa.

Marcinkowska M., 2007, Ocena dziatalności instytucji finansowych, Centrum Doradztwa i Informacji Difin, Warszawa. 
Pawłowicz L., 2003, Projektowane podstawy prawne restrukturyzacji przedsiębiorstwa $w$ kryzysie, [w:] S. Ka s i e w i c z, L. P a wło w i c z (red.), Zarzadzanie wartościa firmy w dobie kryzysu, Wydawnictwo Cedetu, Warszawa.

Pieńkowska M., 2005, Ujęcie upadtości w teorii przedsiębiorstwa, [w:] E. Mąc zyńska (red.), Ekonomiczne aspekty upadtości przedsiębiorstw w Polsce, Szkoła Główna Handlowa w Warszawie, Warszawa.

Pog od zińs k a M., S ojak S., 1995, Wykorzystanie analizy dyskryminacyjnej w przewidywaniu bankructwa przedsiębiorstw, „Acta Universitatis Nicolai Copernici. Ekonomia”, z. XXV(299), Toruń, s. 53-61, [za:] M. Ha mrol, Prognozowanie zagrożenia finansowego przedsiębiorstwa. Wartość predykcyjna polskich modeli analizy dyskryminacyjnej, „Badania Operacyjne i Decyzje" 2008, nr 3.

Prus ak B. (red.), 2007, Ekonomiczne i prawne aspekty upadtości przedsiębiorstw, Difin, Warszawa.

Prus a k B., 2005, Nowoczesne metody prognozowania zagrożenia finansowego przedsiębiorstw, Centrum Doradztwa i Informacji, Difin sp. z o.o., Warszawa.

Rog ow ski W., 2008, Dylematy wykorzystywania w warunkach polskich modeli oceny zagrożenia upadtościq, [w:] E. M ąc zyńs k a (red.), Bankructwa przedsiębiorstw wybrane aspekty instytucjonalne, Szkoła Główna Handlowa w Warszawie, Warszawa.

S u s z yńs ki C., 2003, Wartości poznawcze mierników, [w:] G. K. Ś wi de r s k a (red.), Informacja zarzadcza w procesie formułowania i realizacji strategii firmy, Difin, Warszawa.

Świderska G. K. (red.), 2003, Informacja zarzadcza w procesie formułowania i realizacji strategii firmy, Difin, Warszawa.

Z ale s k a M., 2002, Identyfikacja ryzyka upadtości przedsiębiorstwa i banku. Systemy wczesnego Ostrzegania, Centrum Doradztwa i Informacji Difin, Warszawa.

Zele k A., 2003, Zarzadzanie kryzysem w przedsiębiorstwie - perspektywa strategiczna, Instytut Organizacji i Zarządzania w Przemyśle „ORGMASZ”, Warszawa.

\section{FINANCIAL ANALYSIS AND BANKRUPTCY PREDICTING MODELS AS TOOL FOR THE EVALUATION OF ENTERPRISE FINANCIAL SITUATION}

Knowledge and consciousness of imperfections of used tools is very important when we have to use them because only with this information we can properly evaluate situation especially if it is connected with possibility of preventing bankruptcy of enterprise. In article author tried to sum up the strengths and weaknesses of financial analysis and bankruptcy predicting models in monitoring the financial situation of company to capture potential signals of bankruptcy threat. In many publications we can find very dispersed good and bad sides of use those methods. Those pros and cons usually are obvious and natural, but in need it is hard to mention the most important. What is more, the analysis of strengths and weaknesses of subjected methods helps to understand in better way their specificity and thus apply proper way of its use or to be able to add more important information which will complete view of financial situation of company. The article contains most common, famous causes of bankruptcy, overall classification of bankruptcy prediction methods, and most of all strengths and weaknesses of financial analysis and bankruptcy prediction models.

Key words: bancruptcy predicting, financial analysis, discriminant models, comparison of methods, causes of bancruptcy, strenghts and weaknesses. 